\title{
Article \\ Quantitative Research on Profitability Measures in the Polish Meat and Poultry Industries
}

\author{
Anna Zielińska-Chmielewska ${ }^{1, *(\mathbb{D})}$, Jerzy Kaźmierczyk ${ }^{2} \mathbb{D}$ and Ireneusz Jaźwiński ${ }^{3}$
}

Citation: Zielińska-Chmielewska, A.; Kaźmierczyk, J.; Jaźwiński, I. Quantitative Research on Profitability Measures in the Polish Meat and Poultry Industries. Agronomy 2022, 12, 92. https://doi.org/10.3390/ agronomy12010092

Academic Editors: Djamilia Skripnuk and Gulnara Romashkina

Received: 9 December 2021

Accepted: 24 December 2021

Published: 30 December 2021

Publisher's Note: MDPI stays neutral with regard to jurisdictional claims in published maps and institutional affiliations.

Copyright: (C) 2021 by the authors. Licensee MDPI, Basel, Switzerland. This article is an open access article distributed under the terms and conditions of the Creative Commons Attribution (CC BY) license (https:// creativecommons.org/licenses/by/ $4.0 /)$.
1 Department of Business Activity and Economic Policy, Institute of Economics, Poznan University of Economics and Business, Al. Niepodległości 10, 61-875 Poznań, Poland

2 Department of Education and Personnel Development, Institute of Socio-Economics, Poznan University of Economics and Business, Al. Niepodległości 10, 61-875 Poznań, Poland; jerzy.kazmierczyk@ue.poznan.pl

3 Institute of Spatial Economy and Socio-Economic Geography, Faculty of Economics, Finance and Management, University of Szczecin, ul. Mickiewicza 64, 71-101 Szczecin, Poland; ireneusz.jazwinski@usz.edu.pl

* Correspondence: anna.zielinska@ue.poznan.pl

\begin{abstract}
Business entities strive for continuous adaptation to changing situations and needs. The decisions of business entities entangled in multifaceted processes of economic, social, and environmental progress must be taken on the basis of reliable knowledge, developed know-how, scrupulous recognition of the initial state, and foresight of the multiple consequences of business actions over a long horizon. In such a situation, the measurement of financial efficiency in terms of the profitability of enterprises in meat and poultry industries is extremely desired and provides valuable information on the necessary modifications to reduce the potential risks of business operation. The Polish meat and poultry industries should take into account current and future market requirements, competition, and consumer response. The dynamic progress of technology is forced to take appropriate steps to improve and modernize products, services, and methods of solving profit losses. The aim of the paper is to calculate and evaluate the statistical relationships between profitability ratios in Polish meat and poultry enterprises divided into four groups: slaughterhouses, meat enterprises (small, medium, and large), poultry meat enterprises, and meat trade enterprises. In the theoretical part of the study, methods of descriptive, comparative, deductive, and synthetic analyses were used. In the practical part of the study, panel data from the entire meat and poultry industries in the period from 2010 to 2019 were used. For the measurement of financial efficiency, methods, such as financial indicator analysis, panel database modeling, and nonparametric ANOVA, were applied. The ANOVA method was used to test only the statistically significant relationships between profitability ratios across all groups of examined enterprises in the meat and poultry industries. To summarize, the optimal level of profitability was achieved by all groups of examined enterprises, except small meat enterprises. The highest financial efficiency in the area of profitability was reached by poultry enterprises. Moreover, financial support for small companies in the meat industry can bring tangible benefits such as maintaining a diversified product range locally and transforming small meat companies into buying centers for the local community. Both are effective solutions, especially in view of the post-pandemic situation.
\end{abstract}

Keywords: financial efficiency; profitability; panel data modeling; meat and poultry industries; Poland

\section{Introduction}

Meat, meat products, poultry, and poultry products play an important role in the Polish diet [1]. For many years, pigs and poultry farmers suffered from low procurement prices, significant in the sense of economic efficiency, differences in regional production, and massive, cross-country competition [2].

Regional differences in livestock and live poultry prices disrupt production stability [3]. Farmers and producers operate in an environment characterized by changing markets, 
agri-food policies, and social environments [4]. A number of farmers have no choice but to close down their businesses due to the fact of rising production costs, the excessive volatility of raw material prices, and the lack of institutional support from the state [5]. More market-oriented policies tend to increase price volatility, affecting farm development and profitability [6].

From a consumer point of view, the increase in the price of red meat as a result of inflation causes a reduction in red meat consumption and an increase in poultry consumption. Poultry meat is a cheaper alternate to available animal protein [7]. The quality of meat and meat products involves many parameters such as animal welfare, production systems, and farm safety procedures. The sustainability of animal production is correlated with human satisfaction and animal welfare requirements [8].

Of great importance to the profitability of meat and poultry production are the costs associated with maintaining high hygiene standards, good manufacturing practices (GMPs), standard sanitation operational procedures (SSOPs), and hazard analysis in critical control points (HACCPs) [9-11].

Hiralal (2015) [12] drew attention to the pressing problems of poultry farmers such as the high prices of feed and chicks, the quality of feed and chicks, breeding, diseases, social and marketing problems, and the insufficient knowledge of farmers on profitability issues. He claims that the government should support research activities for the poultry industry and introduce loan facilities and subsidies for farmers.

\subsection{The Meat and Poultry Industries in Poland}

In 2010-2019, the economic and financial performances of meat enterprises testified to a good and secure economic situation. In 2017-2018, meat companies generated a record net profit of PLN 1.7 billion, which was 39\% higher than in 2016 and $42 \%$ higher than in 2010; all of the profitability indicators improved. The average net return on sales of the meat industry rose to $3.07 \%$ of the turnover value and was the highest since 2011. In 2017, compared to 2010 , the equity increased by $42.87 \%$ to PLN 10.7 billion and general debt increased by $10.1 \%$ (to PLN 12.4 billion) of which long-term debt increased by $30.6 \%$ (to PLN 3.6 billion). The significant increase in long-term debt caused the ratio of this debt to operating surplus to increase to 1:10. Capital expenditure reached PLN 1.2 billion and remained at the same level as in 2016. The investment rate was 1.36, more than ensuring the replacement of production assets as well as the upgrading and modernization of meat enterprises. The liquidity amounted to 1.46 , which fully ensured the payment of short-term liabilities. In 2010-2019, the percentage of profitable companies was at a comparable level of $84.44 \%$, and their share in the sector's turnover was nearly $89.40 \%$ (Table 1 ).

In 2010-2019, the economic and financial performances of poultry enterprises testified to their stable economic situation. In 2017, poultry enterprises generated a record net profit of PLN 2.35 billion, which was 5.1\% higher than in 2016 and 12.76\% higher than in 2010. The profitability of net sales in 2017 was twice as lower than the average in the food industry in 2010-2019. In 2017, the average net sales profitability of the poultry industry reached the highest turnover value of $2.35 \%$, but in 2019 , it dropped to 1.89 and was close to its value in 2010. In 2019, the investment rate was 1.48, ensuring the reproduction of production assets. In 2019, liquidity was 1.35, ensuring the repayment of liabilities. Between 2010 and 2019 , total debt was equivalent to $60 \%$ of assets. In 2010-2019, the percentage of profitable companies oscillated around $85.34 \%$, and their share in the sector's turnover was $85.9 \%$ (Table 2). 
Table 1. Key financial indicators of the meat industry in Poland in 2010-2019.

\begin{tabular}{|c|c|c|c|c|c|c|c|c|c|c|c|}
\hline Number & Specification & 2010 & 2011 & 2012 & 2013 & 2014 & 2015 & 2016 & 2017 & 2018 & 2019 \\
\hline 1. & $\begin{array}{l}\text { Net revenues from the sale } \\
\text { of products, goods, and } \\
\text { materials (million PLN) }\end{array}$ & 31,404 & 32,986 & 41,728 & 44,862 & 44,675 & 46,189 & 49,951 & 57,825 & 54,474 & 59,381 \\
\hline 2. & Net profit (million PLN) & 1029 & 680 & 891 & 963 & 1389 & 1447 & 1267 & 1763 & 1762 & 1351 \\
\hline \multirow{3}{*}{$\begin{array}{l}3 . \\
\text { (a) } \\
\text { (b) } \\
\text { (c) }\end{array}$} & $\begin{array}{l}\text { Return on total revenues } \\
\qquad(\%) \\
\text { - Gross }\end{array}$ & 3.76 & 2.29 & 2.45 & 2.36 & 3.35 & 3.40 & 2.86 & 3.41 & 3.54 & 2.61 \\
\hline & - Net & 3.25 & 1.95 & 2.12 & 2.05 & 2.98 & 3.01 & 2.45 & 3.07 & 3.14 & 2.21 \\
\hline & - Capital accumulation * & 5.31 & 3.80 & 3.74 & 3.69 & 4.69 & 4.80 & 4.21 & 4.71 & 4.83 & 3.87 \\
\hline 4. & Equity & 6153 & 6200 & 6709 & 7487 & 8611 & 9648 & 9671 & 10,771 & 10,547 & 11,428 \\
\hline 5. & Total debt & 6325 & 6827 & 8010 & 8475 & 9117 & 9955 & 11,256 & 12,398 & 13,415 & 14,398 \\
\hline 6. & Current liquidity & 1.20 & 1.24 & 1.22 & 1.30 & 1.34 & 1.31 & 1.32 & 1.46 & 1.40 & 1.33 \\
\hline 7. & Investment rate ** & 1.18 & 1.24 & 1.23 & 1.16 & 1.13 & 1.50 & 1.31 & 1.30 & 1.28 & 1.36 \\
\hline \multirow[t]{2}{*}{8.} & $\begin{array}{c}\text { Profitable companies }(\%) \\
\text { - Percentage of profitable } \\
\text { companies }\end{array}$ & 86.9 & 77.3 & 81.3 & 84.1 & 87.3 & 89.0 & 82.2 & 85.3 & 87.8 & 83.1 \\
\hline & $\begin{array}{c}\text { - Their share in industry } \\
\text { revenue }\end{array}$ & 91.1 & 85.8 & 91.4 & 84.5 & 94.9 & 93.99 & 89.9 & 90.9 & 87.3 & 83.9 \\
\hline
\end{tabular}

* Net profit + amortization; ${ }^{* *}$ investment expenditures/amortization. Source: [13].

Table 2. Key financial indicators of the poultry industry in Poland in 2010-2019.

\begin{tabular}{|c|c|c|c|c|c|c|c|c|c|c|c|}
\hline Number & Specification & 2010 & 2011 & 2012 & 2013 & 2014 & 2015 & 2016 & 2017 & 2018 & 2019 \\
\hline 1. & $\begin{array}{l}\text { Net revenues from the sale } \\
\text { of products, goods, and } \\
\text { materials (million PLN) }\end{array}$ & 10,202 & 13,777 & 14,281 & 11,068 & 11,411 & 11,482 & 12,345 & 12,658 & 13,714 & 13,807 \\
\hline 2. & Net profit (million PLN) & 193 & 204 & 180 & 160 & 314 & 235 & 280 & 304 & 455 & 268 \\
\hline \multirow{4}{*}{$\begin{array}{l}3 . \\
\text { (a) } \\
\text { (b) } \\
\text { (c) }\end{array}$} & $\begin{array}{c}\text { Return on total revenues (\%) } \\
\text { - Gross }\end{array}$ & 2.05 & 1.44 & 1.13 & 1.26 & 2.91 & 2.37 & 2.53 & 2.55 & 3.60 & 2.25 \\
\hline & - Net & 1.77 & 1.25 & 1.05 & 1.06 & 2.61 & 2.02 & 2.23 & 2.35 & 3.22 & 1.89 \\
\hline & - Capital accumulation* & 3.30 & 2.68 & 2.60 & 2.44 & 3.93 & 3.53 & 3.87 & 4.09 & 5.00 & 3.79 \\
\hline & Cash flow (\%) & 3.30 & 2.68 & 2.60 & 2.44 & 3.93 & 3.53 & 3.87 & 4.09 & 5.00 & 3.79 \\
\hline 4. & Current liquidity & 1.21 & 1.17 & 1.24 & 1.15 & 1.28 & 1.34 & 1.30 & 1.34 & 1.28 & 1.35 \\
\hline 5. & Investment rate ${ }^{* *}$ & 1.12 & 1.43 & 1.02 & 1.37 & 1.41 & 1.92 & 1.90 & 1.70 & 1.26 & 1.48 \\
\hline \multirow[t]{2}{*}{6.} & $\begin{array}{l}\text { Profitable companies }(\%) \\
\text { - Percentage of profitable } \\
\text { companies }\end{array}$ & 89.4 & 81.3 & 77.6 & 83.1 & 90.7 & 89.3 & 83.6 & 85.5 & 86.1 & 86.7 \\
\hline & $\begin{array}{l}\text { - Their share in industry } \\
\text { revenues }\end{array}$ & 93.1 & 66.2 & 89.5 & 86.2 & 89.1 & 91.00 & 73.40 & 89.80 & 90.00 & 91.00 \\
\hline
\end{tabular}

${ }^{*}$ Net profit + amortization; ${ }^{* *}$ investment expenditures. Source: [14].

\subsection{Economic Efficiency in the Paradigm of Sustainable Development}

Economic efficiency is an ambiguous concept that has been presented from various perspectives in economic and management sciences [15-17].

In a broad sense, economic efficiency is known as an activity that aims to achieve a given effect using the least amount of available resources or to achieve the best result using a given amount of resources [18]. In a narrow sense, economic efficiency is the ratio of the obtained result to inputs [19]. According to the principle of a rational economy, this means 
that certain results should be achieved at the lowest expenditures (i.e., costs) possible, or the best possible result should be obtained with a given quantity of inputs (i.e., costs). The higher the efficiency, the greater the result per unit of effort. First, efficiency can be applied in assessing the effects that are of a quantitative nature as a ratio of the effects to expenditures. In this approach, economic efficiency manifests itself in achieving a specific goal using the most efficient and least wasteful use of resources [20]. Second, efficiency can be applied in assessing the effects that are of a qualitative nature as the ability to achieve the desired effect [21]. In this approach, financial efficiency, in terms of profitability, is assessed using profitability ratios [22].

Economic efficiency refers both to individual entities, such as a company, a household, and the enterprise sector, and the economy of an entire country [23]. Methods commonly used for assessing financial situations are based on a ratio approach [24-27].

Researchers [28-32] across the world agree on the complexity and multifaceted nature of financial stability, known as the ability of a firm to generate profit, increase the value of invested capital, and repay its short- and long-term liabilities at the same time [33]; financial sustainability, known as the profitability, solvency, and efficiency of a firm [34]; sustainable development, known as an organizing principle for meeting human development goals while simultaneously sustaining the ability of natural systems to provide the natural resources and ecosystem services on which the economy and society depend [35].

\subsection{Financial Efficiency in Terms of Profitability in the Meat and Poultry Industries}

A limited number of socio-economic investigations have been conducted on the profitability of the meat and poultry industries [36]. Undoubtedly, the value chain has moved from the farmer towards a retailer [37]. Along with other researchers [38], several authors have also found that the overall economic value of farmers' and meat and poultry processors' work are significantly less than the achieved production and costs incurred [39]. A few possible alternatives to increasing the inequalities in the level of revenues for farmers, processors, and producers consist of vertical integration or production cooperation [40].

Ali et al. (2014) [41] studied the profitability and cost efficiency of open-shed broiler farmers in Punjab, Pakistan. The study proved a positive net profit and a positive rate of return on investment. Bano et al. (2011) [42] revealed the profitability index of open house broiler farms. Over the years in four different and independent studies by Islam (1998) [43], Mohsin et al. (2008) [44], Oladeebo and Ambelamidi (2007) [45], and Sheikh and Zala (2011) [46], they proved that as the size of a broiler increased, the net margin over the invested money per unit increases. Medium- and large-sized farms gained a higher profit on broilers and a lower cost-benefit ratio than small farms. Furthermore, the yearly profit on investment in broiler farming was approximately $20 \%$. Thus, the profit on broiler operation was largely different.

The Polish meat and poultry industries, together, are among the most important food industries, which also include the dairy, fruit and vegetable, and bakery and confectionery industries $[47,48]$. The meat and poultry industries are characterized by a relatively low level of profitability of sales $[13,14]$, and are classified as low-profitability sectors in the food industry, although the poultry industry is typified by higher profitability than the meat industry $[49,50]$.

The authors found current and inspiring contributions to the issue of the systematization of the efficiency measurement. Wasilewski and Zabadała (2012) presented changes in the efficiency of agricultural enterprises depending on the relationship between equity and debt [51]. Filipiak and Jasińska (2017) carried out a multi-faceted classification of the concept and measurement of effectiveness [52]. Waśniewski and Skoczylas (2004) determined the fundamental categories via a financial analysis [53].

The authors found a research gap in the form of methodology and an understanding of a detailed insight into the profitability indicators to support management processes in the sense of the investigation and quantification of relationships among profitability ratios within an economic efficiency framework $[54,55]$. 
The novelty of this manuscript is the presentation, analyses, and assessment of financial efficiency in terms of profitability in the Polish meat and poultry industries. First, a financial method was used to carry out an indicator analysis in terms of profitability. Second, a statistical method (i.e., an ANOVA analysis) was used to determine only statistically significant relationships among the calculated profitability indicators. Third, an econometric method - panel data modeling - was used to combine panel and longitudinal data into multi-dimensional data involving measurements over time. The panel data modeling was applied to a set of five calculated profitability indicators for each of the 758 meat and poultry enterprises for the period 2010-2019. Additionally, for qualitative data, methods, such as analysis, synthesis, and comparisons methods, were used to provide an explanation of existing relationships among the multidimensional data. The simultaneous use of quantitative and qualitative methods made it possible to deepen, broaden, and enrich the conducted analyses.

The scientific aim of the study was to compare four groups of all meat and poultry enterprises in order to show the differences and possible relationships among these companies. The practical aim was to indicate the significance of the calculated profitability indicators.

Many researchers have pointed out the need to assess the economic efficiency of food sector enterprises [1,56-61]. Previous research by Helfert (2001), McCrary (2010), Niemann et al. (2008), Pappas (1998), Williams et al. (2008) [62-66] as well as the authors' empirical studies have led to the following hypothesis: each type of tested profitability indicators differentiates financial efficiency.

The necessity of the research can be included in two research questions:

(1) Have the meat and poultry enterprises reached economic efficiency in the area of profitability?

(2) Are there any statistically significant dependencies between profitability ratios and the meat and poultry enterprises?

In order to answer the first research question, a financial ratio analysis was conducted on the measurement and evaluation of profitability ratios in all 758 meat and poultry enterprises. The characteristics of the values distribution of the profitability ratios is shown in Table 1.

In order to answer the second research question, an ANOVA analysis and panel data modeling on statistically significant correlations between profitability ratios and examined groups of meat and poultry enterprises were used (Tables 6-8).

The remainder of the paper proceeds as follows: Section 1 presents an introductory literature review on the concept, advantages, and disadvantages to the use of financial indicator analysis, the ANOVA method, and panel data modeling. Section 2 introduces the materials and methodology. Section 3 is devoted to the results and discussion. Section 4 presents the conclusion. A reference list along with Appendix A are located at the end of the manuscript. Appendix A contains a structured list of the profitability indicators used in the study together with a detailed description and interpretation of the possible results.

\section{Materials and Methods}

\subsection{Primary and Secondary Research Sources}

In order to assess the financial efficiency in the area of profitability in the Polish meat and poultry industries, well thought-out primary and secondary research sources were used.

The primary research sources come from the financial database of EMIS Intelligence with 42,000 units of raw financial data in the period 2010-2019. In order to evaluate financial efficiency in terms of profitability, 38,000 units of cleaned financial data were used such as net profit; operating profit; operating profit after tax; extraordinary profit; net revenue from the sale of products, goods, and materials; sales revenue; other operating revenues; financial revenue; total assets; total capital; equity. The criteria for the selection of these indicators were (a) key indicators determining profitability; (b) the inclusion of financial and economic dimensions; (c) having a large decision-making and information capacity; 
(d) taking into account the interests of the producer, processor, and entrepreneur; (e) are characterized by a simple formula design. The evaluation of financial efficiency, in terms of the profitability of the examined meat and poultry enterprises, was possible through the interpretation of the results [67].

The secondary research sources came from scientific records, such as published articles, books, bulletins and orders identified through Scopus, Web of Science, and Google Scholar. The search of databases identified 145 documents. The secondary research sources were identified, screened, and finally included in the process of creating the article.

Figure 1 presents the selection of secondary sources according to PRISMA guidelines.

Identification

Screening

Included

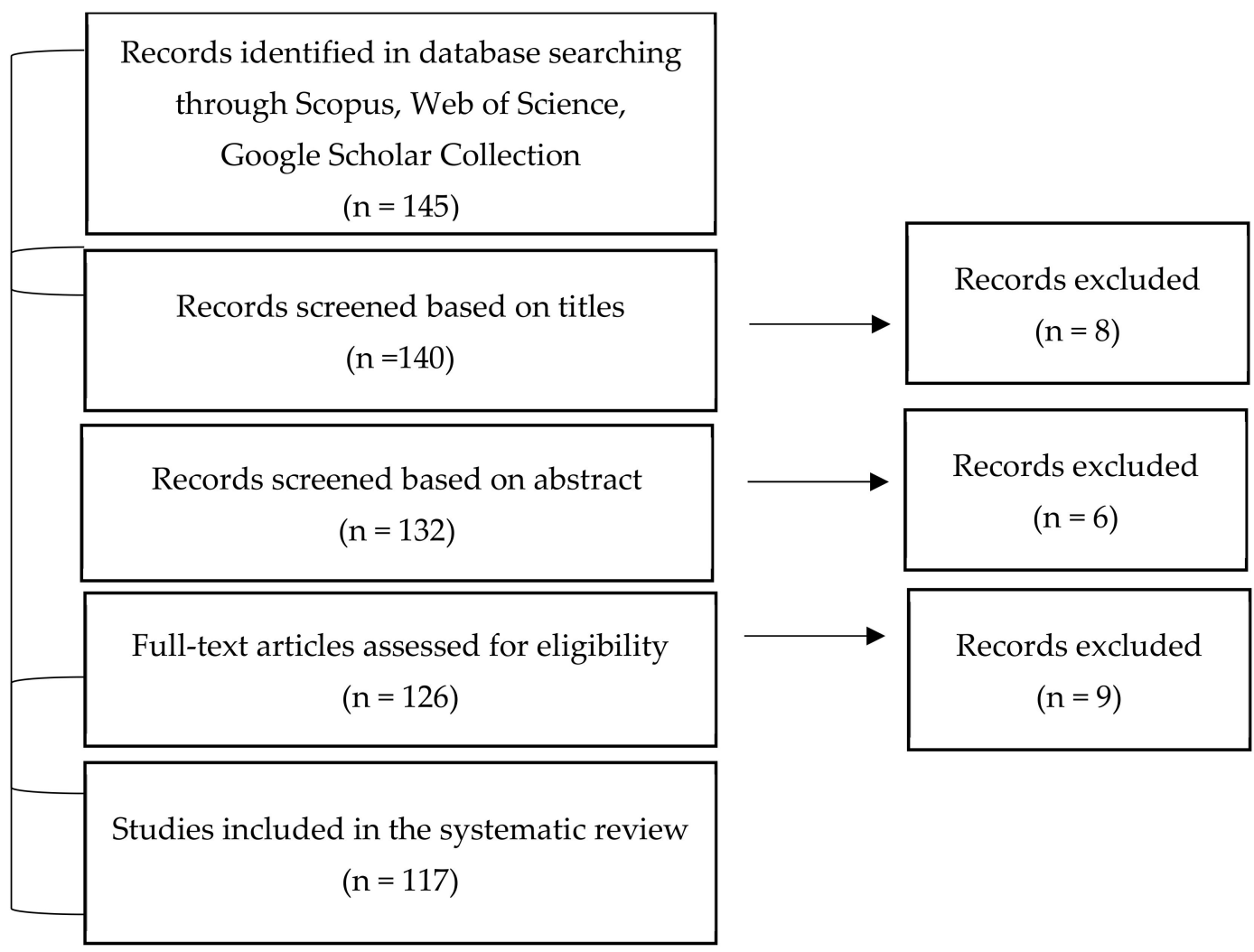

Figure 1. Selection of secondary sources according to PRISMA guidelines.

\subsection{Measures}

Worldwide accounting principles require a company to present a balance sheet and an income statement, along with a variety of additional reports, schedules, and footnotes [68-71].

A panel database was created in order to find and assess relationships between the different profitability ratios in all four groups of meat and poultry enterprises in the Polish meat and poultry industries. The final panel database consisted of 38,000 financial units of 758 enterprises in the period 2010-2019. Data processing was conducted with the statistical program Excel. Calculations for records from the 758 enterprises in the period 2010-2019 were carried out for five profitability indicators (see Appendix A) such as operating profitability (OP), return on total capital (ROI), net return on sales (NRS), return on assets (ROA), and return on equity (ROE). The calculated profitability ratios for all 758 enterprises in the period 2010-2019 were used to run panel data estimations with the use of the ANOVA method only for statistically significant ratios between the four groups of examined meat and poultry enterprises with a significant level equal to zero. Three profitability ratios (i.e., ROE, NRS, and OP) were statistically significant, which resulted in approximate 8455 panel data observations ( 3 ratios $\times 758$ enterprises $\times$ (minimum 3 , maximum 5 years)). 
Figure 2 presents the methodological process of the selection of primary sources.

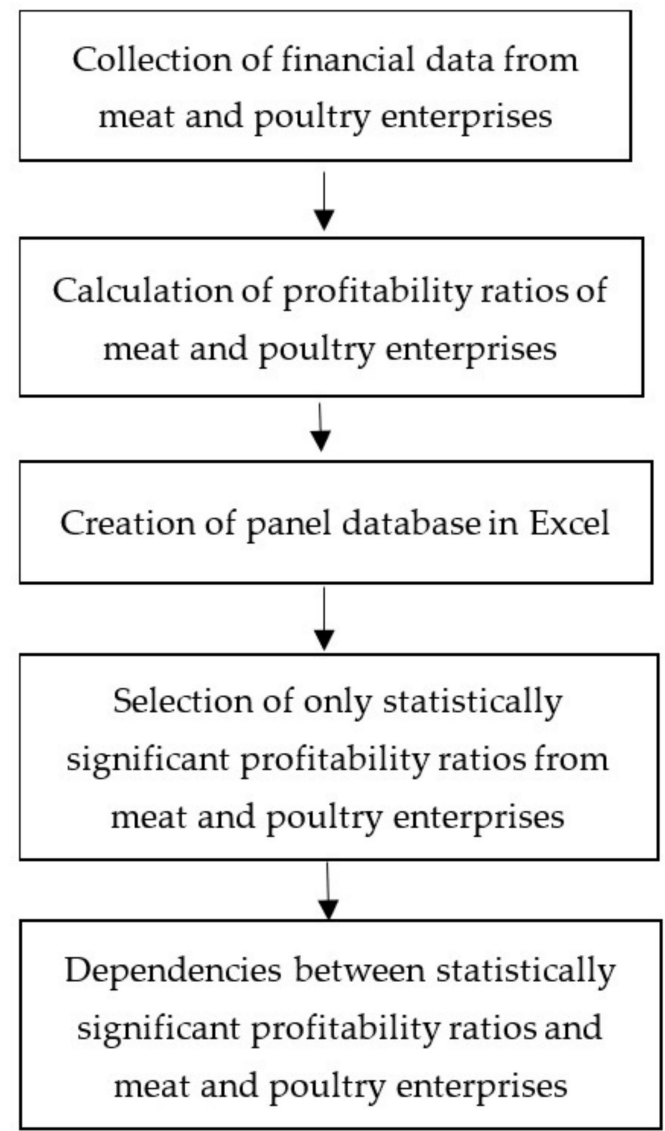

Figure 2. Selection of primary sources according to PRISMA guidelines.

Random effects models and individual effects models were used. The Hausman test better estimates parameters (e.g., consistent and efficient) that occur in random effects models. Hence, the general least squares (GLSM) random effects method was used for parameter estimation. The following selection criteria were adopted to isolate the explanatory variables: (a) correlation analysis was conducted between individual financial indicators (i.e., explanatory variable) and binary variables (i.e., explanatory variables), (b) statistically significant correlation with the explanatory variable was assumed, (c) the variables were assumed to be correlated with each other as little as possible, and (d) panel data estimation of the regression models with fixed and random effects was used. The panel data for the regression models with fixed and random effects were estimated using the general least squares method (GLSM), and panel data in the models came from 758 meat enterprises grouped into 4 groups of enterprises in the period from a minimum 3 to maximum 5 years. The research characteristics are presented in Table 3.

Table 3. Presentation of the research characteristics.

\begin{tabular}{|c|c|c|c|}
\hline Subject & Objects, Country, Time & Measurement Methods and Tools & Goal \\
\hline $\begin{array}{c}\text { Assessment } \\
\text { off inancial efficiency }\end{array}$ & $\begin{array}{l}\text { Database on enterprises } \\
\text { operating in meat and poultry } \\
\text { industries } \\
\text { in Poland in 2010-2019 }\end{array}$ & $\begin{array}{c}\text { Quantitative: indicator analysis, } \\
\text { ANOVA analysis, and panel data } \\
\text { Modeling }\end{array}$ & $\begin{array}{l}\text { A comprehensive study on } \\
\text { financial efficiency in terms of } \\
\text { profitability } \\
\text { in the meat and poultry } \\
\text { industries }\end{array}$ \\
\hline
\end{tabular}




\subsection{Sample and Procedure}

The basic criteria for a research selection sample were:

1. Subject of conducted activity according to PKD 2007 (PKD_Polish Classification of Business Activities)—classes 10.12 and 10.13;

2. Location within the country;

3. Keeping financial statements for the years 2012-2019;

4. Raw material processing volume ( $\mathrm{t} /$ week), number of employees (full-time), and volume of revenue (PLN/year).

The analyzed group of 758 enterprises in the meat and poultry industries were divided into four groups: slaughterhouses, $n=55$; meat enterprises, $n=597$ (subdivided into large meat enterprises; $n=35$, medium size, $n=295$; small enterprises, $n=267$ ); poultry meat enterprises, $n=56$; meat-trading enterprises, $n=50$. Small meat enterprises employ from 10 to 49 persons, process more than 7.5-20 tons of slaughter material per week and obtain sales revenues up to PLN 100 million per year. Medium-sized meat enterprises employ from 50 to 249 people, process 20-100 tons of slaughter material per week, and obtain sales revenues of PLN 101-499 million per year. Large meat enterprises employ over 250 people, process more than 100 tons of slaughter material per week, and obtain sales revenue exceeding 500 million PLN per year. The research was comprehensive (full), because it covered the entire population. This means that the number of all enterprises subjected to the research was equal to the number of enterprises in the population. The study of financial efficiency met the criterion of representativeness.

\subsection{Financial Analysis-Concept, Advantages, and Constraints of Its Use}

Financial analysis is the process of using financial information to assist in investment and financial decision making. Financial analysis helps managers with efficiency analysis and identification of problem areas within the company [72,73]. In addition, it helps managers identify strengths on which the company should build. Externally, financial analysis is useful for credit managers evaluating loan requests and investors considering security purchases [74].

Hafez (2002) [75], Lau and Sholihin (2005) [76], Cardinaels and van Veen-Dirks (2010) [77], and Chen et al. (2009) [78] have proved that it is difficult to assess the financial and non-financial performance of a company in much detail. This is caused by the high variation in the identification, analysis, and evaluation of a company and its industry specifications.

Financial indicator analysis evaluates financial ratios [78]. Ratios are strategic management tools that provides key stakeholders with a concise and systematic way to organize the voluminous data contained in different financial statements [14,79]. Financial ratios refer to the numerical or quantitative relationship between two items or variables [80]. The accounting indicators are created on the basis of historical data from standardized financial statements, the reliability of which results from their preparation by an independent auditor [81].

This relationship can be expressed in various terms such as percentages or fractions [82] (pp. 419-425).

In the literature, financial indicators, also known as ratios, are divided into following the groups [83] (p. 828):

5. Activity ratios that measure how efficiently a company performs day-to-day tasks such as the collection of receivables and management of inventory;

6. Liquidity ratios that measure the company's ability to meet its short-term obligations;

7. Solvency ratios that measure a company's ability to meet long-term obligations. Subsets of these ratios are also known as "leverage" and "long-term debt" ratios;

8. Profitability ratios that measure a company's ability to generate profitable sales from its resources (assets); 
9. Calculation ratios that measure the quantity of an asset or flow (e.g., earnings) associated with ownership of a specified claim (e.g., a share or ownership of the enterprise).

The reasons for using financial indicator analysis are as follow. Firstly, financial indicator analysis accounts for one of the main criterion for the evaluation of business performance [84]. Secondly, financial indicator analysis is known for its simplicity of measurement and universality of application by sector, national, and global economy [85]. Thirdly, financial indicator analysis is characterized by a wide comparability of results over time and space [86]. Fourthly, financial indicator analysis for individual business entities from a given sector, provides a means of obtaining an overview of the economic and financial situation of the sector [87]. Fifthly, financial indicator analysis is useful in various areas, e.g., assessing efficiency, estimating budgets, forecasting, and planning. The financial ratio analysis is also used for comparative purposes, e.g., industry-specific sector comparisons [88]. Sixthly, from the point of view of object of analysis, the performance valuation of meat sector entities can be based on the following categories of indicators: return on investment ratios, profitability ratios, liquidity ratios, and debt ratios [58].

On the other hand, financial indicator analysis is not free of flaws. Firstly, financial indicator analysis is static, which means that the data presented relate to a given period, for example, the end of a reporting year, which makes it difficult to take into account the different dimensions of an enterprise's activities [89]. Secondly, Hopwood (1972) [90] says that financial measures can lead to favorable subordinates' behaviors because of the objectivity and the reduced uncertainty of such measures. Thirdly, Kaplan and Atkinson, 1998 [19] are of the opinion that there are two main reasons for the widespread use of financial performance measures. The first one concerns profit measurements, which directly translate into an organization's always purely financial, long-run objectives [20]. The second one points to the aggregative character of an organization's performance [91].

\subsection{ANOVA Analysis-Concept, Advantages, and Constraints of its Use}

Analysis of variance, known as ANOVA, is a statistical method used to examine observations that depend on one or more factors acting simultaneously [92]. This method explains with what probability the extracted factors can cause differences between the observed group averages [93]. There are two main types of ANOVA: one-way ANOVA and two-way ANOVA [94].

A one-way ANOVA compares the effects of an independent variable on multiple dependent variables as does two-way ANOVA but with more than one independent variable, while a factorial ANOVA extends the number of independent variables even further [95].

The non-parametric ANOVA analysis of variance tests the comparison of variables that have more than two levels (i.e., groups) as well as the simultaneous influence of several factors at once (i.e., MANOVA) with its interaction effects between these factors [96]. Secondly, ANOVA is helpful for multidimensional variables [97]. Thirdly, ANOVA increases statistical power [40]. There are at least two limitations of ANOVA analysis [98]. The first one is that the groups have the same, or very similar, standard deviations. The second limitation concerns its restrictive assumptions [99].

\subsection{Panel Data Modeling-Concept, Advantages, and Constraints of Its Use}

Panel models are special models built from cross-sectional temporal data, e.g., objects $\times$ variables $\times$ periods. They describe a fixed group of objects in more than one period [100]. Thanks to the information on objects and their simultaneous characteristics, in particular, periods, panel data models allow for the reduction in measurement errors, resulting from the omission of important unobservable variables for these objects. These models take into account the influence of two types of factors on the analyzed objects. The first group are those that equally affect the phenomenon in all objects. The second group consists of those that specifically affect individual units of the study. There are three main factors contributing to the development of panel data studies: data availability, the greater capacity 
to model the complexity of human behavior than a single cross-section or time series data, and challenging methodology [101].

The fixed effects model assumes that individual effects are not random, and it is possible to estimate them. These effects in the model may express the presence of some specific and directly unobservable characteristics in groups of companies. They may include different types of qualitative characteristics in the structure of enterprises [102].

The random effects model treats individual effects as part of the random component. In this model individual effects are not estimated, but their dispersion is estimated. It indicates how much of the total random error is due to the time-invariant unobservable characteristics of individual objects. However, linking the individual effects to the random component causes it to self-correlate. Hence, the model cannot be estimated by the classical method. The GLSM is used for estimation [103].

The Hausman test is used to test the goodness of fit between a fixed effects model and a random effects model. The null hypothesis is that individual effects are independent of the explanatory variables; thus, both estimators are unconstrained. In this case, the estimator for the random effects model is considered appropriate. The alternative hypothesis implies that the fixed effects model estimator is unburdened, and the random effects model estimator is loaded. In this case, the estimator for the fixed effects model is considered appropriate [104].

The Kolmogorov-Smirnov test is a non-parametric test used to compare distributions of one-dimensional statistical characteristics. There are two main versions of this test: one for one sample and one for two samples. The one-sample test (called the $\lambda$ Kolmogorov consistency test) examines whether the population distribution for a random variable differs from the assumed theoretical distribution when only a finite number of observations of that variable are known (the statistical sample). This test is used to check whether a variable has a normal distribution. For the purpose of testing normality, minor improvements have been made to the test, known as the Lilliefors test. The two-sample test, on the other hand, allows for the distribution of two random variables to be compared. It has the advantage of being sensitive to differences in the location and shape of the empirical distribution of the samples being compared [105].

The Mann-Whitney U test, also known as the Wilcoxon rank-sum test for two samples, is a semi-nonparametric test for testing whether the values of samples drawn from two independent populations are equally large. It is one of the most popular nonparametric tests of significance. Originally proposed as a shift test for two equal samples by Frank Wilcoxon in 1945; it was later generalized by Henry Mann and Donald Ransom Whitney (1947) for the case of differential samples and for testing stochastic equality $[106,107]$.

\section{Results and Discussion}

Table 4 presents the variation in values of the profitability ratios in all groups of meat and poultry enterprises in Poland in 2010-2019. For analysis, the Kolmogorov-Smirnov test was performed to examine the normal distribution of the analyzed indicators. The article presents only these results for which the explanatory variables were significant. The return on equity (ROE), net return on sales (NRS), and operating profitability (OP) ratios had a normal distribution (critical significance level $>0.05$ ). In the next step, Student's $t$-test analysis and ANOVA analysis of variance were used to analyze these ratios. In the case of return on assets ratios (ROA), a normal distribution was not observed; therefore, Mann-Whitney and Wilcoxon U tests were applied.

Figure 3 shows that in 2010-2019, the average values of the net return on the sales ratio in all (except small meat enterprises) examined groups of meat and poultry enterprises showed a positive return on net sales. The recorded highest values of profitability of net sales in large- and medium-sized meat enterprises were lower than the average values of this indicator for the meat industry $(2.55 \%)$. The ratio of net sales of the poultry meat enterprises was higher than the average value of this indicator for the poultry industry $(1.81 \%)$, which indicates a good financial condition of the examined poultry companies. In the authors' opinion, all (except small meat enterprises) examined groups of meat 
enterprises had lower values of net return on sales ratio, which did not contribute to the increase in the total debt in the group of slaughterhouses, poultry meat enterprises, and large and small meat enterprises as well as trade meat companies in contrast to the observed increase in total debt by $30 \%$ in the whole meat industry [108].

Table 4. Characteristics of the distribution of values of the profitability ratios in the examined groups of meat and poultry enterprises in Poland.

\begin{tabular}{cccccc}
\hline $\begin{array}{c}\text { Specification of } \\
\text { Indicators }\end{array}$ & $\begin{array}{c}\text { Maximum } \\
\text { Minus } \\
\text { Difference }\end{array}$ & $\begin{array}{c}\text { Maximum } \\
\text { Plus } \\
\text { Difference }\end{array}$ & $\begin{array}{c}\text { Sample } \\
\text { Mean }\end{array}$ & $\begin{array}{c}\text { Standard } \\
\text { Deviation }\end{array}$ & $\begin{array}{c}\text { Critical } \\
\text { Significance } \\
\text { Level }\end{array}$ \\
\hline $\begin{array}{c}\text { Operating } \\
\text { profitability (OP) }\end{array}$ & 0.153 & -0.101 & 1.9431 & 0.8017 & $0.200^{\mathrm{ab}}$ \\
\hline $\begin{array}{c}\text { Return on total } \\
\text { capital (ROI) }\end{array}$ & 0.201 & -0.205 & 16.6317 & 2.0534 & $0.002^{\mathrm{a}}$ \\
\hline $\begin{array}{c}\text { Net sales } \\
\text { profitability (NSP) }\end{array}$ & 0.153 & -0.095 & 1.6596 & 0.8571 & $0.200^{\mathrm{ab}}$ \\
\hline $\begin{array}{c}\text { Return on assets } \\
\text { (ROA) }\end{array}$ & 0.301 & -0.208 & 16.7096 & 16.4395 & $0.002^{\mathrm{a}}$ \\
\hline $\begin{array}{c}\text { Return on equity } \\
\text { (ROE) }\end{array}$ & 0.206 & -0.165 & 21.7555 & 19.9371 & $0.134^{\mathrm{a}}$ \\
\hline
\end{tabular}

a Tested for consistency with the normal distribution; ${ }^{b}$ Calculated from the data.

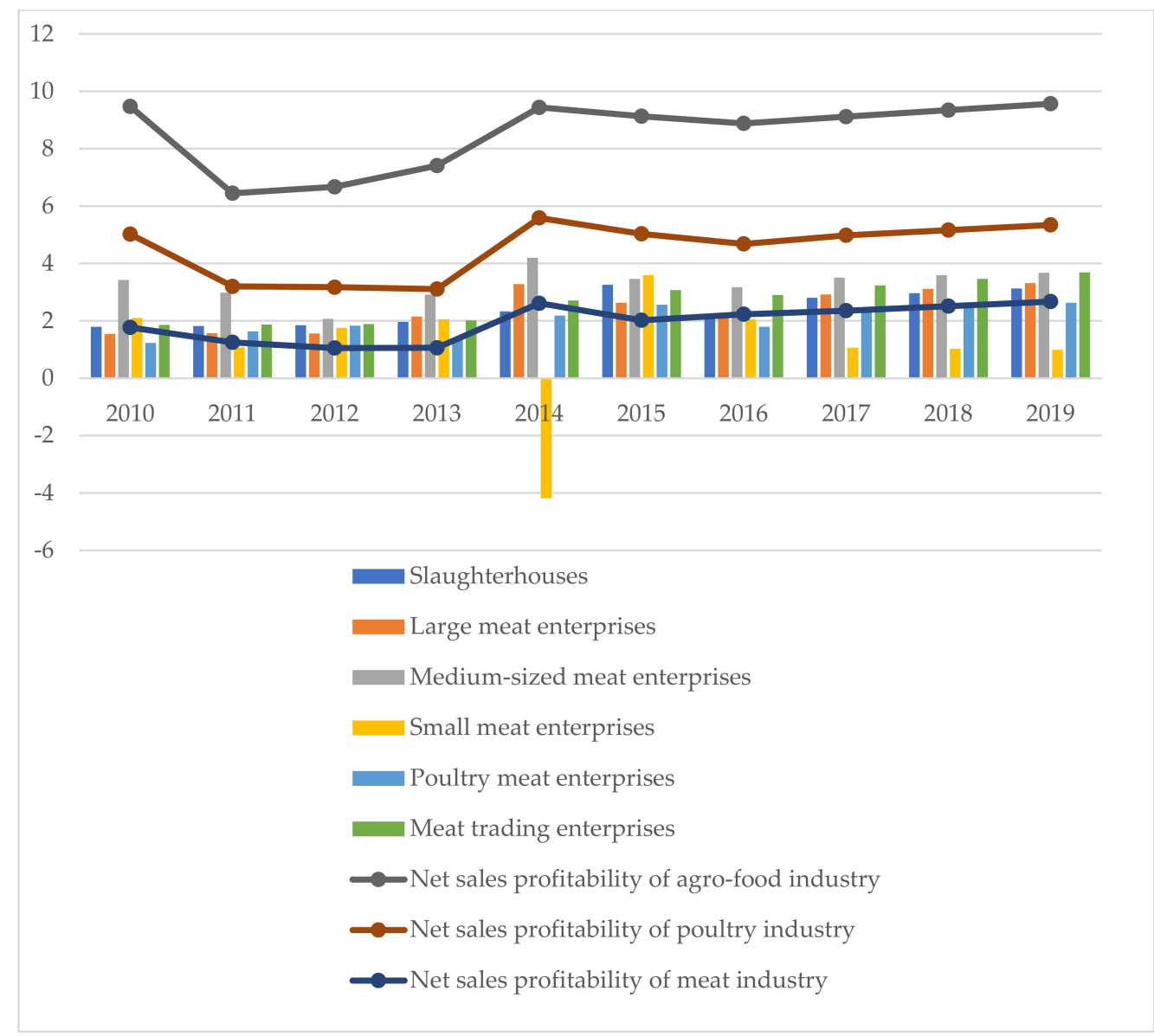

Figure 3. Net return on the sales ratio in the examined four groups of meat and poultry enterprises in comparison with the meat, poultry, and agro-food industries in Poland in 2010-2019. 
Table 5 presents only the statistically significant values of three profitability ratios in all of the examined enterprise groups in the meat and poultry industries in Poland between 2010 and 2019. Slaughterhouses, meat enterprises, poultry meat enterprises, and meat trade enterprises gained varied and positive but not high returns on basic operating activities (OP); positive but low returns on net sales (RNS); positive and high profitability on their own capital (ROE).

Table 5. The presentation of statistically significant profitability ratios in the examined groups of meat and poultry enterprises in Poland in 2010-2019.

\begin{tabular}{|c|c|c|c|c|c|c|c|c|c|c|c|c|c|}
\hline \multirow[b]{2}{*}{ Years } & \multirow[b]{2}{*}{2010} & \multirow[b]{2}{*}{2011} & \multirow[b]{2}{*}{2012} & \multirow[b]{2}{*}{2013} & \multirow[b]{2}{*}{2014} & \multirow[b]{2}{*}{2015} & \multirow[b]{2}{*}{2016} & \multirow[b]{2}{*}{2017} & \multirow[b]{2}{*}{2018} & \multirow[b]{2}{*}{2019} & \multicolumn{3}{|c|}{ Volatility Measures } \\
\hline & & & & & & & & & & & $\begin{array}{c}\text { Average } \\
\text { Value for } \\
2010-2019\end{array}$ & SD & $\begin{array}{l}\text { Coefficient of } \\
\text { Variation (\%) }\end{array}$ \\
\hline \multicolumn{14}{|c|}{ Slaughterhouses $(n=55)$} \\
\hline $\begin{array}{l}\text { Return on equity } \\
\text { (ROE) \% }\end{array}$ & 14.20 & 14.21 & 14.91 & 14.38 & 14.41 & 22.20 & 15.56 & 15.50 & 15.60 & 15.94 & 15.69 & 2.38 & 6.60 \\
\hline $\begin{array}{l}\text { Net return on } \\
\text { sales (NRS) \% }\end{array}$ & 1.79 & 1.82 & 1.85 & 1.96 & 2.61 & 3.26 & 2.23 & 2.18 & 2.36 & 3.12 & 2.17 & 0.43 & 5.11 \\
\hline $\begin{array}{c}\text { Operating } \\
\text { profitability (OP) }\end{array}$ & 2.50 & 2.52 & 2.54 & 2.89 & 2.90 & 3.95 & 2.81 & 2.80 & 2.84 & 2.90 & 2.87 & 0.41 & 6.91 \\
\hline \multicolumn{14}{|c|}{ Meat enterprises $(n=545)$} \\
\hline \multicolumn{14}{|c|}{ Large meat enterprises $(n=35)$} \\
\hline $\begin{array}{l}\text { Return on equity } \\
\quad(\mathrm{ROE}) \%\end{array}$ & 12.10 & 13.12 & 13.89 & 17.36 & 17.35 & 10.56 & 10.62 & 13.19 & 12.67 & 12.40 & 13.33 & 2.37 & 5.62 \\
\hline $\begin{array}{l}\text { Net return on } \\
\text { sales (NRS) \% }\end{array}$ & 1.54 & 1.25 & 1.56 & 2.15 & 3.28 & 2.63 & 2.23 & 2.91 & 3.11 & 3.31 & 2.05 & 0.55 & 3.72 \\
\hline $\begin{array}{c}\text { Operating } \\
\text { profitability (OP) }\end{array}$ & 2.24 & 2.26 & 2.27 & 2.31 & 2.20 & 2.68 & 3.81 & 3.13 & 3.42 & 2.82 & 2.71 & 0.57 & 4.75 \\
\hline \multicolumn{14}{|c|}{ Medium-sized meat enterprises $(n=295)$} \\
\hline $\begin{array}{l}\text { Return on equity } \\
\text { (ROE) \% }\end{array}$ & 17.60 & 17.41 & 14.98 & 14.78 & 18.10 & 19.90 & 17.64 & 17.40 & 17.50 & 17.70 & 17.30 & 1.47 & 11.74 \\
\hline $\begin{array}{l}\text { Net return on } \\
\text { sales (NRS) \% }\end{array}$ & 3.42 & 1.95 & 2.07 & 2.91 & 4.20 & 3.46 & 3.17 & 3.50 & 3.59 & 3.67 & 3.20 & 0.53 & 5.99 \\
\hline $\begin{array}{c}\text { Operating } \\
\text { profitability (OP) }\end{array}$ & 4.04 & 4.97 & & 2.67 & 3.76 & 3.54 & 4.05 & 3.84 & 3.84 & 3.82 & 3.84 & 0.59 & 6.45 \\
\hline \multicolumn{14}{|c|}{ Small meat enterprises $(n=267)$} \\
\hline $\begin{array}{l}\text { Return on equity } \\
\text { (ROE) \% }\end{array}$ & 1.14 & 1.62 & 1.82 & 2.48 & 3.33 & 7.13 & 1.81 & 2.67 & 2.47 & 2.41 & 2.69 & 1.68 & 1.60 \\
\hline $\begin{array}{l}\text { Net return on } \\
\text { sales (NRS) \% }\end{array}$ & 2.10 & 1.77 & 1.07 & 1.83 & $|4.18|$ & 2.05 & 3.59 & 2.06 & 1.06 & 0.98 & 2.30 & 0.90 & 2.55 \\
\hline $\begin{array}{c}\text { Operating } \\
\text { profitability (OP) }\end{array}$ & 2.49 & 2.50 & 2.52 & 3.44 & 1.63 & 4.88 & 2.91 & 2.91 & 3.01 & 3.08 & 2.94 & 0.84 & 3.50 \\
\hline \multicolumn{14}{|c|}{ Poultry meat enterprises $(n=56)$} \\
\hline $\begin{array}{l}\text { Return on equity } \\
\text { (ROE) } \%\end{array}$ & 13.20 & 13.40 & 14.08 & 13.60 & 8.65 & 11.04 & 12.33 & 12.20 & 12.01 & 11.80 & 12.23 & 1.57 & 7.81 \\
\hline $\begin{array}{l}\text { Net return on } \\
\text { sales (NRS) \% }\end{array}$ & 1.23 & 1.63 & 1.83 & 1.63 & 2.61 & 2.18 & 2.56 & 1.80 & 2.51 & 2.63 & 1.79 & 0.38 & 4.77 \\
\hline $\begin{array}{c}\text { Operating } \\
\text { profitability (OP) }\end{array}$ & 2.50 & 2.64 & 2.52 & 2.54 & 2.79 & 2.51 & 2.97 & 2.63 & 2.42 & 2.21 & 2.57 & 0.21 & 12.51 \\
\hline
\end{tabular}


Table 5. Cont.

\begin{tabular}{|c|c|c|c|c|c|c|c|c|c|c|c|c|c|}
\hline \multirow[b]{2}{*}{ Years } & \multirow[b]{2}{*}{2010} & \multirow[b]{2}{*}{2011} & \multirow[b]{2}{*}{2012} & \multirow[b]{2}{*}{2013} & \multirow[b]{2}{*}{2014} & \multirow[b]{2}{*}{2015} & \multirow[b]{2}{*}{2016} & \multirow[b]{2}{*}{2017} & \multirow[b]{2}{*}{2018} & \multirow[b]{2}{*}{2019} & \multicolumn{3}{|c|}{ Volatility Measures } \\
\hline & & & & & & & & & & & $\begin{array}{c}\text { Average } \\
\text { Value for } \\
2010-2019\end{array}$ & SD & $\begin{array}{l}\text { Coefficient of } \\
\text { Variation (\%) }\end{array}$ \\
\hline \multicolumn{14}{|c|}{ Meat trading enterprises $(n=50)$} \\
\hline $\begin{array}{l}\text { Return on equity } \\
\text { (ROE) \% }\end{array}$ & 18.76 & 18.77 & 18.78 & 17.56 & 19.54 & 19.70 & 16.16 & 18.47 & 17.71 & 16.67 & 18.21 & 1.17 & 15.61 \\
\hline $\begin{array}{l}\text { Net return on } \\
\text { sales (NRS) \% }\end{array}$ & 1.86 & 1.87 & 1.89 & 2.01 & 2.02 & 3.07 & 2.91 & 3.20 & 3.46 & 3.68 & 2.28 & 0.46 & 4.98 \\
\hline $\begin{array}{c}\text { Operating } \\
\text { profitability (OP) }\end{array}$ & 2.44 & 2.45 & 2.47 & 2.62 & 3.21 & 3.56 & 2.39 & 2.73 & 2.64 & 2.44 & 2.70 & 0.39 & 6.94 \\
\hline
\end{tabular}

Tables 6-8 present the estimation results of econometric models investigating the statistically significant dependencies between profitability indicators and the analyzed groups of meat and poultry enterprises. Only statistically significant dependencies of financial efficiency are presented.

Table 6. Panel data estimation results for the variable return on equity (ROE) — general least squares method (GLSM).

\section{Model 1: Panel Data Estimation-758 Observations \\ Time Series Length: Minimum 3, Maximum 5 Robust Standard Errors (Robust HAC)}

\begin{tabular}{ccccc}
\hline Variables & Coefficient & Standard Error & Z & Critical Significance Level \\
\hline Const & 36.2469 & 6.522051 & 5.56 & $<0.000$ \\
\hline Slaughterhouses & -11.50156 & 7.878275 & -1.46 & $<0.144$ \\
\hline Meat enterprises & -9.53371 & 6.74018 & -1.41 & $<0.157$ \\
\hline $\begin{array}{c}\text { Poultry meat } \\
\text { enterprises }\end{array}$ & -18.62808 & 7.990935 & -2.33 & $<0.020$
\end{tabular}

Test: Chi-Square (2) $=6.02$; Critical significance level $=0.1107$

The value of ROE was significantly lower by $18,628(p$-value $=0.020)$ in Interpretation of poultry meat enterprises than in other groups of enterprises. For the zero-one the model variable analyses, meat and meat product traders were the base variable and are not included in the outcome Tables 4-6

Conclusions There were statistically significant differences in the level of obtained values for the ROE ratio by groups of meat industry enterprises.

\begin{tabular}{cc}
\hline Hypothesis $\mathrm{H}_{1}$ & Each type of tested profitability differentiates financial efficiency \\
\hline Decision on $\mathrm{H}_{1}$ & Reject $\mathrm{H}_{1}$ \\
\hline Summary & $\begin{array}{c}\text { Profitability measured by the value of ROE differentiated the group of meat } \\
\text { enterprises. The obtained estimation results did not confirm hypothesis } \mathrm{H}_{1}, \\
\text { because the ROE value significantly differentiated only poultry meat } \\
\text { enterprises. The results of the model may complement } \mathrm{H}_{1} \text { by fulfilling a } \\
\text { cognitive function. }\end{array}$ \\
\hline
\end{tabular}

Table 6 presents the panel data estimation results for the variable ROE. It was proven that there was a statistically significant dependency between the value of ROE and poultry meat enterprises. It means that only the coefficient of poultry meat enterprises was statistically significant. Thus, poultry meat enterprises had a lower ROE ratio than the other groups of examined enterprises.

In 2010-2019, the ROE of the agro-food industry was at a high level of $10-14 \%$, several times higher than the profits achieved on other safe bank deposits of capital. In the analyzed period, higher changes in the profitability level between 8.99 and $11.84 \%$ 
were recorded in the processing of animal products than in the processing of plant products [109], resulting from the development of the high profitability of owning capital which stimulated producers.

Table 7. Panel data estimation results for the variable net return on sales (NRS)—general least squares method (GLSM).

\begin{tabular}{|c|c|c|c|c|}
\hline \multicolumn{5}{|c|}{$\begin{array}{l}\text { Model 2: Panel Data Estimation-758 Observations } \\
\text { Time Series Length: Minimum 3, Maximum } 5 \\
\text { Robust Standard Errors (Robust HAC) }\end{array}$} \\
\hline Variables & Coefficient & Standard Error & $\mathrm{Z}$ & Critical Significance Level \\
\hline Const & 5.059239 & 1.119018 & 4.52 & $<0.000$ \\
\hline Slaughterhouses & -2.782779 & 1.351669 & -2.06 & $<0.040$ \\
\hline Meat enterprises & -0.6000481 & 1.156463 & -0.52 & $<0.604$ \\
\hline $\begin{array}{l}\text { Poultry meat } \\
\text { enterprises }\end{array}$ & -2.752528 & 1.37098 & -2.01 & $<0.045$ \\
\hline \multicolumn{5}{|c|}{ Test: Chi-Square $(2)=13.09 ;$ Critical significance level $=0.0044$} \\
\hline $\begin{array}{l}\text { Interpretation of } \\
\text { the model }\end{array}$ & \multicolumn{4}{|c|}{$\begin{array}{l}\text { The value of the NRS was significantly lower by } 2.782 \text { (critical level of } \\
\text { significance }=0.040 \text { ) in slaughterhouses, and by } 2.752 \text { (critical level of } \\
\text { significance }=0.045 \text { ) in poultry processing enterprises than in meat } \\
\text { enterprises and trade and service meat enterprises. }\end{array}$} \\
\hline Conclusions & \multicolumn{4}{|c|}{$\begin{array}{l}\text { There were statistically significant differences in the level of obtained values } \\
\text { of the net sales profitability ratio in slaughterhouses and poultry meat } \\
\text { enterprises. }\end{array}$} \\
\hline Hypothesis $\mathrm{H}_{1}$ & \multicolumn{4}{|c|}{ Each type of tested profitability differentiated financial efficiency. } \\
\hline Decision on $\mathrm{H}_{1}$ & \multicolumn{4}{|c|}{ Do not reject $\mathrm{H}_{1}$} \\
\hline Summary & \multicolumn{4}{|c|}{$\begin{array}{l}\text { Profitability measured by the value of the NRS differentiated the group of } \\
\text { meat enterprises. The obtained estimation results confirmed hypothesis } \mathrm{H}_{1} \text {, } \\
\text { because the value of the NRS ratio significantly differentiated both } \\
\text { slaughterhouses and poultry meat enterprises. }\end{array}$} \\
\hline
\end{tabular}

Table 7 presents the panel data estimation results for the variable NRS. It was proven that there is a statistically significant dependency between the value of NRS and slaughterhouses and poultry meat enterprises. This means that the coefficient of slaughterhouses and poultry meat enterprises were statistically significant. Thus, slaughterhouses and poultry meat enterprises had a lower NRS ratio than other groups of examined enterprises. The meat industry belongs to sections of the agro-food industry with a lower return on sales (the highest return on sales were observed in sections such as the production of beverages, breweries, and confectionaries). Nevertheless, in the period 2010-2019, the economic and financial performance of enterprises in the red meat industry testified to a good and secure economic situation [36,49].

Table 8 presents the panel data estimation results for the variable OP. It was proven that there was a statistically significant dependency between the value of OP and meat enterprises. This means that the coefficient of meat enterprises was statistically significant. Thus, meat enterprises had a higher OP ratio than other groups of examined enterprises. Slaughterhouses had slightly different results from meat enterprises and meat trade enterprises, which requires further in-depth analyses, and it is worth investigating the reasons for this situation. 
Table 8. Panel data estimation results for the variable operating profitability (OP)—general least squares method (GLSM).

\begin{tabular}{|c|c|c|c|c|}
\hline \multicolumn{5}{|c|}{$\begin{array}{l}\text { Model 3: Panel Data Estimation-758 Observations } \\
\text { Time Series Length: Minimum 3, Maximum } 5 \\
\text { Robust Standard Errors (Robust HAC) }\end{array}$} \\
\hline Variables & Coefficient & Standard Error & $\mathrm{Z}$ & Critical Significance Level \\
\hline Const & 2.646011 & 0.8977534 & 2.95 & $<0.003$ \\
\hline Slaughterhouses & 0.1182097 & 1.242771 & 0.10 & $<0.924$ \\
\hline Meat enterprises & 2.583077 & 0.9568674 & 2.70 & $<0.007$ \\
\hline $\begin{array}{l}\text { Meat trade } \\
\text { enterprises }\end{array}$ & 2.908654 & 1.554172 & 1.87 & 0.061 \\
\hline \multicolumn{5}{|c|}{ Test: Chi-Square $(2)=13.31$; Critical significance level $=0.0040$} \\
\hline $\begin{array}{l}\text { Interpretation of } \\
\text { the model }\end{array}$ & \multicolumn{4}{|c|}{$\begin{array}{c}\text { The value of the OP ratio was significantly higher by } 2.583 \text { (critical level of } \\
\text { significance }=0.007 \text { ) in meat enterprises than in slaughterhouses and poultry } \\
\text { processing enterprises. }\end{array}$} \\
\hline Conclusions & \multicolumn{4}{|c|}{$\begin{array}{l}\text { There were statistically significant differences in the level of the obtained } \\
\text { value of the OP ratio in meat enterprises rather than in slaughterhouses and } \\
\text { poultry meat enterprises. }\end{array}$} \\
\hline Hypothesis $\mathrm{H}_{1}$ & \multicolumn{4}{|c|}{ Each type of tested profit abilities differentiated financial efficiency. } \\
\hline Decision on $\mathrm{H}_{1}$ & \multicolumn{4}{|c|}{ Reject $\mathrm{H}_{1}$} \\
\hline Summary & \multicolumn{4}{|c|}{$\begin{array}{l}\text { Profitability measured by the value of the OP ratio differentiated groups of } \\
\text { meat enterprises. The obtained estimation results did not confirm hypothesis } \\
\mathrm{H}_{1} \text {, because the value of the OP ratio significantly differentiated only meat } \\
\text { enterprises. The results of the model may complement } \mathrm{H}_{1} \text { by fulfilling a } \\
\text { cognitive function }\end{array}$} \\
\hline
\end{tabular}

\section{Conclusions}

On the basis of the obtained results and cross-referenced similar results indicated by other authors, it can be concluded that profitability is worth being investigated. The verification of a set of profitability indicators in the Polish meat and poultry industries by the econometric method in accordance with the adopted research procedure made it possible to formulate two general conclusions:

10. There was a wide variation in terms of profitability in all four groups of analyzed enterprises;

11. The evaluation of the enterprises' profitability ratios showed statistical significance for the rise in profitability for ROE, NRS, and OP, which means that enterprises should invest and upgrade their own capital to gain market advantage and compete with other companies as well as scrutinize their ability to pay back the loans.

According to the conducted research, the hypothesis that financial efficiency is related to the type of examined efficiency was positively verified, because:

12. The ROE ratio significantly differentiated poultry meat enterprises, which means that due to the fact of their fast production turnover, they can gain a higher return on equity;

13. NRS significantly differentiated slaughterhouses and poultry meat enterprises, and they must pay close attention to the size of their credit burden;

14. OP significantly differentiated meat enterprises, which means they have to cope with the high demands on the price and quality of their products. Summarizing the results of the study, the following specific conclusions can be drawn:

15. Profitability reached the highest values in the examined poultry meat enterprises;

16. The positive level of profitability (except for small meat enterprises) was achieved by all groups of examined enterprises; 
17. The examined small meat enterprises had the largest difficulties in maintaining the optimal level of profitability.

Some of the limitations of this research were the difficulties concerning the construction of the measures, which were static and anchored in the past. The second limitation concerned the issue that financial ratios do not tend to take into account environmental taxes and fees and the fact that the accounting results do not align with the generated cash flows. It is advisable to analyze and compare financial flows and the profitability ratios of the analyzed meat and poultry industries enterprises.

However, the restrictions of financial analysis are related to the impossibility of valuing the entire enterprise in its equally important non-financial aspects and the short-term nature of performance assessments, resulting from analyses based on historical data. In connection with the abovementioned limitations, the authors have taken steps to search for optimal methods for efficient measurement using non-financial elements that provide the capacity for a more complex assessment of a company.

The results of the article are a solid contribution to the identification, clarification, and assessment of the financial efficiency of the Polish meat and poultry industries. The findings may serve as a helpful and practical tool for managers and other business stakeholders through supporting financial decision-making processes.

The specific two conclusions are as follow:

18. Based on the researchers' field experiences, farmers, producers, processers, and wholesalers as well as retailers in the meat and poultry industries have vivid evidence that keeping a detailed record on profitability ratios will enable them to use this knowledge to run a successful business and reduce the risk of insolvency. Moreover, the results of the panel data modeling offer a reference for potential profitability paths by developing different meat and poultry production tracks;

19. State authorities and government institutions dealing with the meat and poultry industries should focus on financial support in the form of credit and loans.

There were three research limitations that the researchers found impossible to eliminate. The first one was due to the high fragmentation of actors in the meat production chain. The second obstacle was an institutional constraint, namely, the limited financial support for meat producers. The third restriction involved the level of profitability of the meat and poultry industries resulting from the upward, cost-intensive trend of animal welfare-oriented production systems.

Although formidable, effective implementation of general policies in meat and poultry industries involves the formation of flexible but interconnected production and processing sites to safeguard meat and poultry production for every country's regions.

As in the research by Bieniek-Majka, M. and Matuszczak, A. (2017) [110,111], the differences in gained profitability resulted from the different levels in the financial liquidities of the analyzed groups of meat and poultry enterprises.

To sum up, a characteristic feature of the meat industry in Poland is the mismatch between the maturity of assets in relation to the maturity of current liabilities [112]. Consequently, as a result of the long collection period of receivables and short maturity of current liabilities, there is a clear cash gap in meat industry enterprises, requiring an additional source of financing [113]. It is reasonable to reduce unnecessary costs due to the fact of external financing as well as the inappropriate use of the financial leverage effect and simultaneous reduction in the cost of equity capital [114].

Author Contributions: A.Z.-C. (conceptualization, data curation, investigation, methodology, project administration, supervision, and writing-original draft); J.K. (formal analysis, validation, and writing-original draft); I.J. (formal analysis, investigation, visualization, writing-review and editing). All authors have read and agreed to the published version of the manuscript.

Funding: The project was financed within the framework of the program of the Ministry of Science and Higher Education (Poland) under the name "Regional Excellence Initiative" in the years 2019-2022; project number: 001/RID/2018/19; amount of financing PLN 10,684,000.00. 
Institutional Review Board Statement: Not applicable.

Informed Consent Statement: Not applicable.

Data Availability Statement: The study did not report any data.

Conflicts of Interest: No conflict of interest.

\section{Appendix A}

Table A1. The presentation of the financial efficiency indicators in the area of profitability.

\begin{tabular}{|c|c|c|c|}
\hline Number & Name of The Ratio & Explanation of the Profitability Ratio & Average Values in the Sector \\
\hline 1. & $\begin{array}{l}\text { Operating profitability }(\mathrm{OP})= \\
\text { (operating profit) } /(\text { sales } \\
\text { revenue + other operating } \\
\text { revenue) }\end{array}$ & $\begin{array}{l}\text { The operating profitability ratio measures the } \\
\text { relationship between profit (loss) on total } \\
\text { operations and sales in value terms. The ratio } \\
\text { takes into account other operating activities in } \\
\text { the assessment of profitability, thus increasing or } \\
\text { decreasing the profitability of the core business } \\
\text { by a partial result achieved on other operating } \\
\text { activities }\end{array}$ & 9.82 \\
\hline 2. & $\begin{array}{c}\text { Return on total capital }(\mathrm{ROI})= \\
\text { Operating profit after } \\
\text { tax } / \text { total capital } \times 100 \%\end{array}$ & $\begin{array}{l}\text { The return on investment ratio measures the } \\
\text { effectiveness of a company's operations, as it } \\
\text { estimates how much profit a company can count } \\
\text { on by investing one monetary unit. Due to the } \\
\text { fact of its versatility and ease of calculation, the } \\
\text { ratio is often used to compare the profitability of } \\
\text { several investments and can be expressed as a } \\
\text { percentage or value. }\end{array}$ & $\begin{array}{l}\text { The higher, } \\
\text { the better }\end{array}$ \\
\hline 3. & $\begin{array}{l}\text { Net return on sales }(\mathrm{NRS})= \\
\text { net profit } / \text { (net revenue from } \\
\text { the. sale of products, goods, } \\
\text { and materials }+ \text { other } \\
\text { operating revenue }+ \text { financial } \\
\text { revenue }+ \text { extraordinary } \\
\text { profits) } \times 100 \%\end{array}$ & $\begin{array}{l}\text { The return on sales ratio shows how much net } \\
\text { profit remains in the company from sales. This } \\
\text { means that thanks to the ratio, one can } \\
\text { determine how much profit is earned on each } 1 \\
\text { monetary unit acquired from sales. The amount } \\
\text { of the ratio depends to a large extent on the } \\
\text { industry of the company and the length of the } \\
\text { turnover cycle and the company's sales volume. }\end{array}$ & $3.87 \%$ \\
\hline 4. & $\begin{array}{c}\text { Return on assets }(\mathrm{ROA})= \\
\text { net profit/total assets } \times 100 \%\end{array}$ & $\begin{array}{l}\text { The return on assets ratio informs on the } \\
\text { company's ability to generate profits and the } \\
\text { efficiency of asset management. }\end{array}$ & $8.79 \%$ \\
\hline 5. & $\begin{array}{l}\text { Return on equity }(\mathrm{ROE})= \\
\text { net profit/equity } \times 100 \%\end{array}$ & $\begin{array}{c}\text { The return on equity ratio shows how much } \\
\text { profit a company generates from the contributed } \\
\text { equity. }\end{array}$ & $14.85 \%$ \\
\hline
\end{tabular}

\section{References}

1. Zielińska-Chmielewska, A. Ocena Efektywności Ekonomicznej Przedsiębiorstw Mięsnych w Polsce (Assesment of Economic Efficiency of Meat Enterprises in Poland); Wydawnictwo UE w Poznaniu: Poznań, Poland, 2020.

2. Zielińska-Chmielewska, A.; Mruk-Tomczak, D.; Wielicka-Regulska, A. Qualitative Research on Solving Difficulties in Maintaining Continuity of Food Supply Chain on the Meat Market during the COVID-19 Pandemic. Energies 2021, 14, 5634. [CrossRef]

3. Havlíček, J.; Dömeová, L.; Smutka, L.; Řezbová, H.; Severová, L.; Šubrt, T.; Šrédl, K.; Svoboda, R. Efficiency of Pig Production in the Czech Republic and in an International Context. Agriculture 2020, 10, 597. [CrossRef]

4. Boggia, R.; Zunin, P.; Turrini, F. Functional Foods and Food Supplements. Appl. Sci. 2020, 10, 8538. [CrossRef]

5. Baráth, L.; Fertő, I. Productivity and Convergence in European Agriculture. J. Agric. Econ. 2016, 68, 228-248. [CrossRef]

6. Šrédl, K.; Prášilová, M.; Severová, L.; Svoboda, R.; Štěbeták, M. Social and Economic Aspects of Sustainable Development of Livestock Production and Meat Consumption in the Czech Republic. Agriculture 2021, 11, 102. [CrossRef]

7. Mian, M.A.; Malik, M.S. Variations in Profitability of Different Size of Commercial Broiler Poultry Farms in Central Region of Khyber Pakhtunkhwa. Sarhad J. Agric. 2021, 37, 858-867.

8. Spedding, C.R.W. Sustainability in animal production systems. Anim. Sci. 1995, 61, 1-8. [CrossRef] 
9. Dan, S.D.; Platon, S.; Mihaiu, M.; Jecan, C.; Cordea, D.; Cordis, I.V.; Lapusan, A. Microbial Risk Assessment in the Main Steps of Poultry Slaughter. Bull. UASVM Vet. Med. 2013, 70, 214-222.

10. Kelly, L.A.; Gettinby, H.E.; Fazil, G.A.; Snary, E.; Wooldridge, M. Microbiological safety of poultry meat: Risk assessment as a way forward. World's Poult. Sci. J. 2003, 59, 495-508. [CrossRef]

11. Mead, G.C. Microbiological quality of poultry meat: A review. Braz. J. Poult. Sci. 2004, 6, 135-142. [CrossRef]

12. Hiralal, J. Problems of Poultry Farming. 2015. Available online: www.krishisewa.com/articles/livestock/575-poultry-farmingproblem (accessed on 1 September 2021).

13. Zawadzka, D.; Pasińska, D. Przetwórstwo [Meat processing]. Rynek Mięsa (Meat Mark.) 2017, 53, 49-52.

14. Pasińska, D. Przetwórstwo [Poultry Meat Processing]. Rynek Drobiu Jaj [Poult. Egg Mark.] 2018, 53, 10-13.

15. Jaźwiński, I. Kapitał Ludzki w Polityce Regionalnej (Human Capital in Regional Policy); Wydawnictwo Naukowe Uniwersytetu Szczecińskiego: Szczecin, Poland, 2017.

16. Kotane, I.; Kuzmina-Merlino, I. Assessment of financial indicators for evaluation of business performance. Eur. Integr. Stud. 2012, 6, 216-224. [CrossRef]

17. Narkunienè, J.; Ulbinaitè, A. Comparative analysis of company performance evaluation methods. Entrep. Sustain. Issues 2018, 6 , 125-138. [CrossRef]

18. Black, J. Słownik konomii; Wydawnictwo Naukowe PWN: Warsaw, Poland, 2008.

19. Kaplan, R.S.; Atkinson, A.A. Advanced Management Accounting, 3rd ed.; Prentice-Hall: Hoboken, NJ, USA, 1998.

20. Alexander, D.; Britton, A.; Jorissen, A. International Financial Reporting and Analysis, 6th ed.; Cengage Learning EMEA: Andover, UK, 2014.

21. Zielińska-Chmielewska, A.; Kaźmierczyk, J.; Andrianova, E.V. Advantages and Constraints of Eco-Efficiency Measures: The Case of the Polish Food Industry. Agronomy 2021, 11, 299. [CrossRef]

22. De Toni, A.; Tonchia, S. Performance measurement systems-Models, characteristics and measures. Int. J. Oper. Prod. Manag. 2001, 21, 46-71. [CrossRef]

23. Rutherford, D. Routledge Dictionary of Economics; Taylor\& Francis Group: London, UK, 2002.

24. Zbierowski, P. Organizacja wysokiej efektywności. In Uwarunkowania i Prawidtowości Gospodarcze Wywierajace Wptyw na Efektywność Funkcjonowania Przedsiębiorstw; Dudycz, T., Ed.; Politechnika Wrocławska: Wrocław, Poland, 2008; Volume 10, pp. 69-79.

25. Kowalski, Z. Wybrane problemy definiowania i oceny efektywności gospodarowania w rolnictwie (Selected problems of defining and evaluating management efficiency in agriculture, Zeszyty Naukowe). Zag. Ekon. Rolnej 1992, 1, $2-22$.

26. Wilkin, J. Efektywność a sprawiedliwość (Effectiveness and Justice). 1997. Available online: www.for.org.pl (accessed on 1 October 2019).

27. Pietrzak, M. Efektywność finansowa spółdzielni mleczarskich - koncepcja oceny [Financial efficiency of dairy cooperatives a concept for evaluation. In Wydawnictwo Szkoły Głównej Gospodarstwa Wiejskiego w Warszawie; Wydawnictwo Szkoły Głównej Gospodarstwa Wiejskiego w Warszawie: Warszawa, Poland, 2006; ISBN 8372448175.

28. Diantimala, Y. The mediating effect of sustainability disclosure on the relationship between financial performance and firm value. J. Account. Financ. Audit. Stud. 2018, 4, 32-48.

29. Financing for Sustainable Development Report; The Inter-Agency Task Force on Financing for Development United Nations: New York, NY, USA, 2019.

30. Modigliani, F.; Pogue, G.A. An introduction to risk and return: Concepts and evidence, part one. Financ. Anal. J. 1974, 30, 68-80. [CrossRef]

31. Solow, R. Intergenerational equity and exhaustible resources. Rev. Econ. Stud. 1974, 41, 29-45. [CrossRef]

32. Stiglitz, J. Growth with exhaustible natural resources: Efficient and optimal growth paths. Rev. Econ. Stud. 1974, 41, 123-137. [CrossRef]

33. Myšková, R.; Hájek, P. Comprehensive assessment of firm financial performance using financial ratios and linguistic analysis of annual reports. J. Int. Stud. 2017, 10, 96-108. [CrossRef]

34. Zabolotnyy, S.; Wasilewski, M. The Concept of Financial Sustainability Measurement: A Case of Food Companies from Northern Europe. Sustainability 2019, 11, 5139. [CrossRef]

35. Jaźwiński, I. Elementy Ekonomii i Polityki Społecznej (Elements of Social Economics and Policy); Polskie Towarzystwo Ekonomiczne: Szczecin, Poland, 2007.

36. Mroczek, R. Przetwórstwo [Meat Processing]. Rynek Mięsa (Meat Mark.) 2018, 55, 49-51.

37. Kuipers, A.; Malak-Rawlikowska, A.; Stalgienè, A.; Ule, A.; Klopčič, M. European Dairy Farmers' Perceptions and Responses towards Development Strategies in Years of Turbulent Market and Policy Changes. Agriculture 2021, 11, 293. [CrossRef]

38. Rahman, S.; Kazal, M.M.H.; Begum, I.A.; Alam, M.J. Competitiveness, Profitability, Input Demand and Output Supply of Maize Production in Bangladesh. Agriculture 2016, 6, 21. [CrossRef]

39. Havlíček, J.; Šrédl, K.; Řezbová, H.; Smutka, L.; Dömeová, L.; Severová, L.; Šubrt, T.; Svoboda, R. International aspects of the pork production value chain in the Czech Republic. Int. J. Value Chain. Manag. 2021, 12, 241-266.

40. Ismail, D.; Majid, T.A.; Roosli, R. Analysis of Variance of the Effects of a Project's Location on Key Issues and Challenges in Post-Disaster Reconstruction Projects. Economies 2017, 5, 46. [CrossRef]

41. Ali, S.; Asif, R.; Nawaz, M. Profitability and cost efficiency analysis of open shed broiler farmers in Punjab, Pakistan. Int. J. Econ. Comm. Manag. 2014, 2, 1-10. 
42. Bano, R.; Shah, H.; Sharif., M.; Akhtar, W. Profitability index and capital turn over in open house broiler farming: A case study of district Rawalpindi. J. Agric. Res. 2011, 24, 1-4.

43. Islam, F. An Analytical Evaluation of Broiler Farm Unit in Malakand Agency. Life Sci. Int. J. 2016, 1.

44. Mohsin, A.Q.; Riaz, R.; Asad, S.; Mushtaq, A. A profitability analysis of broiler production in Rawalpindi District. Pak. J. Agric. Sci. 2008, 45, 514-519.

45. Oladeebo, J.O.; Ambe-Lamidi, A.I. Profitability, input elasticities and economic efficiency of poultry production among youth farmer in Osun State, Nigeria. Int. J. Poult. Sci. 2007, 6, 994-998. [CrossRef]

46. Shaikh, A.S.; Zala, Y.C. Production Performance and Economic Appraisal of Broiler Farms of Gujarat. Agric. Econ. Res. Rev. 2011, 24, 317-323.

47. Rynek Mięsa (Meat Market). Summary 2020, 59, 5-7.

48. Rynek Drobiu Jaj (Poultry and Egg Market). Summary 2020, 58, 4-5.

49. Pasińska, D. Przetwórstwo [Poultry Meat Processing]. Rynek Drobiu Jaj [Poult. Egg Mark.] 2018, 54, 10-13.

50. Pasińska, S. Przetwórstwo [Poultry Meat Processing]. Rynek Drobiu Jaj [Poult. Egg Mark.] 2019, 55, 10-12.

51. Wasilewski, M.; Zabadała, P. Efektywność przedsiębiorstw rolniczych w zależności od relacji kapitału własnego do obcego [Efficiency of agricultural enterprises as a function of the equity/foreign capital ratio]. In Ekonomika $i$ Organizacja Gospodarki Żywnościowej; No. 99; Wydawnictwo SGGW: Warsaw, Poland, 2012.

52. Filipiak, B.; Jasińska, E. Changes in the approach to measuring efficiency of public healthcare organizations. Zesz. Nauk. Wyższej Szkoty Bank. Pozn. 2018, 78, 87-101. [CrossRef]

53. Waśniewski, T.; Skoczylas, W. Teoria i Praktyka Analizy Finansowej w Przedsiębiorstwie [Theory and Practice of Financial Analysis in Business]; Fundacja Rozwoju Rachunkowości w Polsce [Foundation for the Development of Accounting in Poland]: Warsaw, Poland, 2004.

54. Jaki, A. Mechanizmy procesu zarządzania wartością przedsiębiorstwa (Mechanisms of the enterprise value management process). Zesz. Nauk. Uniw. Ekon. Krakowie 2012, 215, 150-152.

55. Mensch, G. Finanz-Controlling. In Finanzplanung und Kontrolle. Controlling zur Finanziellen Unternehmungsführung, 2nd ed.; Oldenburg Verlag: München, Germany, 2008; p. 417.

56. Czerwińska-Kayzer, D.; Florek, J.; Staniszewski, R.; Kayzer, D. Application of Canonical Variate Analysis to Compare Different Groups of Food Industry Companies in Terms of Financial Liquidity and Profitability. Energies 2021, 14, 4701. [CrossRef]

57. Kandpal, V.; Kavidayal, P.C. Implication of working capital management on the profitability: A case of ONGC LTD, India. Commer. Manag. 2013, 4, 49-53. [CrossRef]

58. Malak-Rawlikowska, A.; Głębska, M.; Hoste, R.; Leeb, C.; Montanari, C.; Wallace, M.; de Roest, K. Developing a Methodology for Aggregated Assessment of the Economic Sustainability of Pig Farms. Energies 2021, 14, 1760. [CrossRef]

59. Mijic, K.; Zekic, S.; Jaksic, D.; Vuković, B. Meat industry in Serbia: Performance analysis of meat-processing and livestock companies. Custos Agronegocio 2014, 10, 124-144.

60. Zielińska-Chmielewska, A.; Alihodzić, A.; Smutka, L. Theoretical and practical concepts of financial efficiency in food processing enterprises. In Proceedings of the 8th International Scientific Symposium Economy of Eastern Croatia-Vision and Growth, Jossip Juraj Strossmayer University of, Osijek, Osijek, Croatia, 29-30 May 2019; pp. 1086-1096.

61. Zimon, G.; Zimon, D. The Impact of Purchasing Group on the Profitability of Companies Operating in the Renewable Energy Sector-The Case of Poland. Energies 2020, 13, 6588. [CrossRef]

62. Helfert, E.A. The Nature of Financial Statements: The Income Statement. Financial Analysis-Tools and Techniques-A Guide for Managers; McGraw-Hill: New York, NY, USA, 2001.

63. McCrary, S. Mastering Financial Accounting Essentials. In The Critical Nuts and Bolts; John Wileyand Sons, Inc.: Hoboken, NJ, USA, 2010

64. Niemann, M.; Schmidt, J.H.; Neukirchen, M. Improving performance of corporate rating prediction models by reducing financial ratio heterogeneity. J. Bank. Financ. 2008, 32, 434-446. [CrossRef]

65. Pappas, A.A. Financial Accounting-Theoretical and Practical Issues, Vol. A; Mpenos, E. Press: Athens, Greece, 1998.

66. Williams, J.R.; Haka, S.F.; Bettner, M.S.; Carcello, J.V. Financial and Managerial Accounting; McGraw-Hill, Irwin: New York, NY, USA, 2008.

67. Bititci, U.S. Overview of popular performance measurement models and frameworks. In Managing Business Performance: The Science and the Art; TJ International Ltd.: Padstow, UK, 2015; pp. 251-262. [CrossRef]

68. Baccarini, D. The concept of project complexity a review. Int. J. Proj. Manag. 1996, 14, 201-204. [CrossRef]

69. Cheng, C.S. The incremental information content of earnings and cash flow from operations affected by their extremity. J. Bus. Financ. Account. 2003, 30, 73-116. [CrossRef]

70. Straub, J.T. The Agile Manager's Guide to Understanding Financial Statements; Velocity Business Publishing: Bristol, VT, USA, 1997.

71. Su, L. A rule extraction based approach in predicting derivative use for financial risk hedging in construction companies. In Proceedings of the International Conference on Information, Management, Innovation Management and Industrial Engineering 2011, Shenzhen, China, 26-27 November 2011; pp. 397-400.

72. American Management Association. How to build a high-performance organization. In A Global Study of Current Trends and Future Possibilities 2007-2017; Copyright 2007; American Management Association. Available online: http://www.gsu.edu/ images/HR/HRI-high-performance07.pdf (accessed on 1 December 2021). 
73. Skripnuk, D.F.; Davydenko, V.A.; Romashkina, G.F.; Khuziakhmetov, R.R. Consumer Trust in Quality and Safety of Food Products in Western Siberia. Agronomy 2021, 11, 257. [CrossRef]

74. Sievänen, M.; Suomala, P.; Paranko, O. Activity-Based Costing and Product. In Proceedings of the 5th International Seminar on Manufacturing Accounting Research, Pisa, Italy, 6-8 June 2001; pp. 1-14.

75. Hafeez, K.; Zhang, Y.B.; Malak, N. Determining key capabilities of a firm using analytic hierarchy process. Int. J. Prod. Econ. 2002, 76, 39-51. [CrossRef]

76. Lau, C.H.; Sholihin, M. Financial and non-financial performance measures: How do they affect job satisfaction? Br. Account. Rev. 2005, 37, 389-413. [CrossRef]

77. Cardinaels, E.; van Veen-Dirks, P.M.G. Financial versus non-financial information: The impact of information organization and presentation in a Balanced Scorecard. Account. Organ. Soc. 2010, 35, 565-578. [CrossRef]

78. Chen, J.S.; Tsou, H.T.; Huang, A.Y.H. Service Delivery Innovation: Antecedents and Impact on Firm Performance. J. Serv. Res. 2009, 12, 36-55. [CrossRef]

79. Tangen, S. Performance measurement: From philosophy to practice. Int. J. Product. Perform. Manag. 2004, 53, 726-737. [CrossRef]

80. Kim, J.; Im, C. Study on Corporate Social Responsibility (CSR): Focus on Tax Avoidance and Financial Ratio Analysis. Sustainability 2017, 9, 1710. [CrossRef]

81. Choong, K.K. Understanding the features of performance measurement system: A literature review. Meas. Bus. Excell. 2013, 17, 102-121. [CrossRef]

82. Suarez, V.; Lesneski, C.; Denison, D. Making the case for using financial indicators in local public health agencies. Am. J. Public Health 2011, 101, 419-425. [CrossRef]

83. Robinson, T.R.; van Greuning, H.; Henry, E.; Broihahn, M.A. International Financial Statement Analysis; CFA Institute, John Wiley \& Sons, Inc.: Hoboken, NJ, USA, 2009.

84. Öcal, M.E.; Oral, E.L.; Erdis, E.; Vural, G. Industry financial ratios-Application of factor analysis in Turkish construction industry. Build. Environ. 2007, 42, 385-392. [CrossRef]

85. Chavan, M. The balanced scorecard: A new challenge. J. Manag. Dev. 2009, 28, 393-406. [CrossRef]

86. Zielińska-Chmielewska, A.; Smutka, L.; Kotyza, P.; Alihodźić, A. The measurement of financial efficiency in terms of debt in meat sector. The case of Poland. In Proceedings of the International Scientific Symposium "Region, Entrepreneurship, Development", Osijek, Croatia, 16 June 2021.

87. Štefko, R.; Vašani cová, P.; Jen`cová, S.; Pachura, A. Management and Economic Sustainability of the Slovak Industrial Companies with Medium Energy Intensity. Energies 2021, 14, 267. [CrossRef]

88. Benos, T.; Kalogeras, N.; Wetzels, M.; de Ruyter, K.; Pennings, J.M.E. Harnessing a 'Currency Matrix' for Performance Measurement in Cooperatives: A Multi-Phased Study. Sustainability 2018, 10, 4536. [CrossRef]

89. Bhasin, M. A study of economic value added disclosures in the annual reports: Is EVA a superior measure of corporate performance? East Asian J. Bus. Econ. 2017, 5, 10-26. [CrossRef]

90. Hopwood, A.G. An empirical study of the role of accounting data in performance evaluation. empirical research in accounting: Selected studies. J. Account. Res. 1972, 10, 156-182. [CrossRef]

91. Cohen, S.; Thiraios, D.; Kandilorou, M. Performance parameters interrelations from a balanced scorecard perspective: An analysis of Greek companies. Manag. Audit. J. 2008, 23, 485-503. [CrossRef]

92. Shaban, A.; Shalaby, S.A.; Di Gravio, G.; Patriarca, R. Analysis of Variance Amplification and Service Level in a Supply Chain with Correlated Demand. Sustainability 2020, 12, 6470. [CrossRef]

93. Md Isa, H.A.; Ismail, M.M.; Samsuddin, N.S.; Abdurofi, I. Profitability of broiler contract farming: A case study in Johor and Sabah. Int. J. Bus. Soc. 2019, 20, 521-532.

94. Zhang, J.-T. Analysis of Variance for Functional Data; Chapman and Hall/CRC: London, UK, 2013.

95. ANOVA (Analysis of Variance): Definition \& Methods//Qualtrics. Available online: https://www.qualtrics.com/au/experiencemanagement/research/anova/ (accessed on 1 May 2021).

96. Wilcox, R.R. Understanding the Practical Advantages of Modern ANOVA Methods. J. Clin. Child Adolesc. Psychol. 2002, 31, 399-412. [CrossRef]

97. Görzen, E.; Diekötter, T.; Meyerink, M.; Kretzschmar, H.; Donath, T.W. The Potential to Save Agrestal Plant Species in an Intensively Managed Agricultural Landscape through Organic Farming-A Case Study from Northern Germany. Land 2021, 10, 219. [CrossRef]

98. Marelli, S.P.; Madeddu, M.; Mangiagalli, M.G.; Cerolini, S.; Zaniboni, L. Egg Production Systems, Open Space Allowance and Their Effects on Physical Parameters and Fatty Acid Profile in Commercial Eggs. Animals 2021, 11, 265. [CrossRef] [PubMed]

99. What Are the Limitations of ANOVA in SPSS? Available online: www.techwalla.com/articles/what-are-the-limitations-of-anovain-spss (accessed on 1 August 2021).

100. Andrei, J.V.; Chivu, L.; Gheorghe, I.G.; Grubor, A.; Sedlarski, T.; Sima, V.; Subic, J.; Vasic, M. Small and Medium-Sized Enterprises, Business Demography and European Socio-Economic Model: Does the Paradigm Really Converge? J. Risk Financ. Manag. 2021, 14, 64. [CrossRef]

101. Hsiao, C. Panel Data Analysis-Advantages and Challenges. Test 2007, 16, 1-22. [CrossRef]

102. Ahrens, H. Analiza wariancji (Analysis of Variance); PWN: Warsaw, Poland, 1970. 
103. Stock, J.H.; Watson, M.W. Introduction to Econometrics, 4th ed.; Harward University Mark W. Watson Princeton University: New York, NY, USA, 2019; Available online: https: / /www.pearsonhighered.com/.../3/4/0134610989.pdf (accessed on 1 December 2021).

104. Eadie, W.; Drijard, D.; James, F.; Roos, M.; Sadoulet, B. Statistical Methods in Experimental Physics, 4th ed.; Amsterdam, Harward University Mark W. Watson Princeton University: New York, NY, USA, 1971.

105. Corder, G.; Foreman, D. Nonparametric Statistics for Non-Statisticians: A Step-by-Step Approach; John Wiley \& Sons: Hoboken, NJ, USA, 2009.

106. Mann, H.; Whitney, D. On a test of whether one of two random variables is stochastically larger than the other. Ann. Math. Stat. 1947, 18, 50-60. [CrossRef]

107. Wilcoxon, F. Individual comparisons by ranking methods. Biom. Bull. 1945, 1, 196-202. [CrossRef]

108. Mroczek, R. Przetwórstwo mięsa. Rynek mięsa. Stan i perspektywy (Meat Processing. The Meat Market. State of Play and Prospects); IERiGŻ-PIB: Warsaw, Poland, 2017.

109. Mroczek, R. (Ed.) Przemiany Strukturalne Przemystu Spożywczego w Polsce i UE na tle Wybranych Elementów Otoczenia Zewnętrznego. Monografie Programu Wieloletniego 2015-2019 (Structural Transformation of the Food Industry in Poland and the EU Against the Background of Selected Elements of the External Environment. Monographs of the Multiannual Programme 2015-2019); IERiGŻ-PIB: Warsaw, Poland, 2016.

110. Bieniek-Majka, M.; Matuszczak, A. Profitability of Kuyavian-Pomeranian fruit and vegetable producers and organizators. Zesz. Nauk. Szkoły Głównej Gospod. Wiej. Warszawie Probl. Rol. Swiat. 2017, 17, 7-16. [CrossRef]

111. Wasilewski, M.; Gałecka, A. Rentowność kapitału własnego gospodarstw rolniczych w zależności od bieżącej płynności finansowej [Return on equity of agricultural holdings in relation to current liquidity]. Zesz. Nauk. Ekon. Organ. Gospod. Żywnościowej 2010, 81, 231-240.

112. Urban, R. Przetwórstwo Mięsa. Rynek Mięsa-Stan i Perspektywy, [Meat Processing. The Meat Market-State and Prospects]; Wydawnictwo Instytutu Rolnictwa i Gospodarki Żywnościowej: Warsaw, Poland, 2012; Volume 43, pp. 1-5.

113. Drewnowska, B. Widmo upadłości wisi nad Rynkiem Mięsnym [The Spectre of Bankruptcy Hangs over the Meat Market]. 2010 Available online: http:/ /www.parkiet.com/artykul/894003.html (accessed on 1 November 2021).

114. Bereżnicka, J.; Pawlonek, T. Optimum kapitałowe w ocenie rentowności wybranych przedsiębiorstw w branży mięsnej [Capital optimum in the assessment of profitability of selected companies in the meat industry]. Zagadnienia Ekon. Rolnej [Probl. Agric. Econ.] 2014, 3, 136-153. 